\title{
Biochemical parameters of silver catfish (Rhamdia quelen) after transport with eugenol or essential oil of Lippia alba added to the water
}

\author{
J. Salbego ${ }^{a}$, C. Toni ${ }^{b}$, A. G. Becker ${ }^{c}$, C. C. Zeppenfeld ${ }^{a}$, C. C. Menezes ${ }^{d}$, V. L. Loro ${ }^{\text {, }}$ \\ B. M. Heinzmann ${ }^{e}$ and B. Baldisserotto ${ }^{a *}$ \\ aDepartamento de Fisiologia e Farmacologia, Universidade Federal de Santa Maria - UFSM, Campus Camobi, \\ Avenida Roraima, 1000, CEP 97105-900, Santa Maria, RS, Brazil \\ 'Instituto Federal de Educação, Ciência e Tecnologia Farroupilha, Campus Frederico Westphalen, Linha 7 de Setembro, \\ s/n, CEP 98400-000, Frederico Westphalen, RS, Brazil \\ 'Laboratório Associado - CIMAR, Centro de Ciências do Mar - CCMAR, Universidade do Algarve - UAlg, \\ Campus de Gambelas, Estrada da Penha, CEP 8005-139, Faro, Portugal \\ dDepartamento de Química, Universidade Federal de Santa Maria - UFSM, Campus Camobi, Avenida Roraima, \\ 1000, CEP 97105-900, Santa Maria, RS, Brazil \\ eDepartamento de Farmácia Industrial, Universidade Federal de Santa Maria - UFSM, Campus Camobi, \\ Avenida Roraima, 1000, CEP 97105-900, Santa Maria, RS, Brazil \\ *e-mail: bbaldisserotto@hotmail.com
}

Received: October 7, 2015 - Accepted: July 20, 2016 - Distributed: November 31, 2017

(With 3 figures)

\begin{abstract}
The transport of live fish is a routine practice in aquaculture and constitutes a considerable source of stress to the animals. The addition of anesthetic to the water used for fish transport can prevent or mitigate the deleterious effects of transport stress. This study investigated the effects of the addition of eugenol (EUG) (1.5 or $\left.3.0 \mu \mathrm{L} \mathrm{L}^{-1}\right)$ and essential oil of Lippia alba (EOL) (10 or $20 \mu \mathrm{L} \mathrm{L}^{-1}$ ) on metabolic parameters (glycogen, lactate and total protein levels) in liver and muscle, acetylcholinesterase activity (AChE) in muscle and brain, and the levels of protein carbonyl (PC), thiobarbituric acid reactive substances (TBARS) and nonprotein thiol groups (NPSH) and activity of glutathione- $S$-transferase in the liver of silver catfish (Rhamdia quelen; Quoy and Gaimard, 1824) transported for four hours in plastic bags (loading density of $\left.169.2 \mathrm{~g} \mathrm{~L}^{-1}\right)$. The addition of various concentrations of EUG $\left(1.5\right.$ or $\left.3.0 \mu \mathrm{L} \mathrm{L}^{-1}\right)$ and EOL $\left(10\right.$ or $\left.20 \mu \mathrm{L} \mathrm{L}^{-1}\right)$ to the transport water is advisable for the transportation of silver catfish, since both concentrations of these substances increased the levels of NPSH antioxidant and decreased the TBARS levels in the liver. In addition, the lower liver levels of glycogen and lactate in these groups and lower AChE activity in the brain (EOL 10 or $20 \mu \mathrm{L} \mathrm{L}^{-1}$ ) compared to the control group indicate that the energetic metabolism and neurotransmission were lower after administration of anesthetics, contributing to the maintenance of homeostasis and sedation status.
\end{abstract}

Keywords: anesthetic, metabolism, stress, fish transportation.

\section{Parâmetros bioquímicos do jundiá (Rhamdia quelen) após transporte com eugenol ou óleo essencial de Lippia alba adicionado à água}

\section{Resumo}

O transporte de peixes vivos é uma prática rotineira na aquicultura e constitui uma fonte considerável de estresse para os animais. A adição de anestésicos na água utilizada para o transporte de peixes pode prevenir ou mitigar os efeitos nocivos do estresse de transporte. Este estudo investigou os efeitos da adição de eugenol (EUG) (1,5 ou 3,0 mL L $\left.{ }^{-1}\right)$ e óleo essencial de Lippia alba (OEL) (10 ou $20 \mathrm{~mL} \mathrm{~L}^{-1}$ ) em parâmetros metabólicos (níveis de glicogênio, lactato e proteína total) no fígado e músculos, a atividade da acetilcolinesterase (AChE) no músculo e no cérebro, e os níveis de proteína carbonil (PC), ácido tiobarbitúrico (TBARS) e grupos tióis não proteicos (NPSH) e atividade da glutationa-S-transferase no fígado de jundiás (Rhamdia quelen; Quoy e Gaimard, 1824) transportados por quatro horas em sacos plásticos (densidade de carga de 169,2 $\left.\mathrm{g} \mathrm{L}^{-1}\right)$. A adição de várias concentrações de EUG (1,5 ou 3,0 $\left.\mathrm{mL} \mathrm{L}^{-1}\right)$ e OEL (10 ou $\left.20 \mathrm{~mL} \mathrm{~L}^{-1}\right)$ na água de transporte é aconselhável para o transporte do jundiá, uma vez que ambas concentrações destas substâncias aumentaram os níveis do antioxidante NPSH e diminuíram os níveis de TBARS no fígado. Além disso, os níveis mais baixos de glicogénio e lactato no fígado destes grupos e menor atividade de AChE no cérebro (EOL 10 ou $20 \mathrm{~mL} \mathrm{~L}^{-1}$ ) em comparação com o grupo controle indicam que o metabolismo energético e neurotransmissão foram menores após a administração dos anestésicos, contribuindo para a manutenção do estado de homeostase e sedação.

Palavras-chave: anestésico, metabolismo, estresse, transporte de peixes. 


\section{Introduction}

During stressful situations, such as transport, fish demand greater amounts of energy, which can be obtained from glycogenolysis, gluconeogenesis and increases in protein turnover (Mommsen et al., 1999; Pankhurst, 2011). The use of anesthetics at sedative concentrations during fish transport could be an important tool to reduce sensitivity to stimuli, swimming time and stress (Ross and Ross, 2008; Zahl et al., 2010).

The metabolic and antioxidant responses of fish exposed to anesthetics have been scarcely investigated (Azambuja et al., 2011; Becker et al., 2012, 2016; Salbego et al., 2014, 2015; Toni et al., 2015). Transportation in closed systems leads to changes in the metabolic state of fish and may lead to oxidative damage through the production of reactive oxygen species (ROS). The increase in ROS production often results in lipid peroxidation (which can be measured by thiobarbituric acid-reactive substances (TBARS) concentration), protein damage and decreased antioxidant protection. ROS may spontaneously react with nucleophilic centers in the cell and also covalently bind to DNA, RNA and protein (Matés, 2000). Oxidized proteins can also form carbonyl groups (PC), which represent a marker of oxidative damage.

In order to protect against oxidative stress, organisms have developed antioxidant defenses (Goyal et al., 2013) which include enzymes such as superoxide dismutase and catalase (Salbego et al., 2014, 2015). In addition, glutathione-S-transferase (GST) is an important detoxifying enzyme that is frequently induced under adverse conditions, such as poisoning. Activation of non-enzymatic antioxidant defenses, such as non-protein thiol groups (NPSH), are also important to aquatic organisms (Salbego et al., 2014, 2015).

Acetylcholinesterase (AChE) is an enzyme present in cholinergic synapses and at motor end plates, which is responsible for degrading acetylcholine (ACh) at the synaptic level, and is extremely important for many physiological functions in fish (Blenau et al., 2012; Salbego et al., 2014). The effect of anesthetics on AChE activity is poorly documented (Mazzanti et al., 1986; Lintern et al., 2000). Although a relationship between Ach activity and anesthesia has emerged (Hudetz et al., 2003; Leung et al., 2011), to our knowledge the effects of anesthetic products on the cholinergic system of fish are still poorly understood.

Eugenol (EUG) (4-allyl-2-metoxy-phenol), the main component of clove oil, is a well-studied anesthetic for fish (Roubach et al., 2005; Gonçalves et al., 2008; Cunha et al., 2010a; Becker et al., 2012; Parodi et al., 2012). Some recent studies have demonstrated that the essential oil of Lippia alba (EOL) (Mill.) N.E. Brown is also a suitable anesthetic and/or sedative for aquatic animals (Cunha et al., 2010b; Parodi et al., 2012; Salbego et al., 2014; Becker et al., 2016; Toni et al., 2015). Both extracts have been shown to be effective in minimizing the effects of transport stress in some fish species when added to the water during transportation (Cooke et al., 2004; Azambuja et al., 2011;
Becker et al., 2012, 2016); however, the efficacy of EOL in altering biochemical parameters and oxidative stress apparently depends on the concentration administered (Salbego et al., 2014) and analysis of the effect of EUG on biochemical parameters after stress is limited. Thus, the aim of this study was to investigate the effects of EUG and EOL (at concentrations able to induce only sedation in fish) on metabolic responses and AChE activity, as well as to analyze the oxidative parameters (TBARS and PC levels) and enzymatic (GST) antioxidant activity in silver catfish after four hours of transport. The silver catfish was chosen because it is the main native species raised in fish cultures of southern Brazil (Baldisserotto et al., 2010; Villares Junior and Goitein, 2015).

\section{Material and Methods}

\subsection{Experimental procedure}

Fish (weight: $301.24 \pm 21.40$ g; length: $28.90 \pm 1.30 \mathrm{~cm}$ ) were transported in closed plastic bags containing $7 \mathrm{~L}$ of water and $8 \mathrm{~L}$ of pure oxygen, at a loading density of $169.2 \mathrm{~g} \mathrm{~L}^{-1}$ for four hours. Fish were divided into five treatment groups (in triplicate, $\mathrm{n}=12$ per group), each receiving one of the following treatments: control (water only), 1.5 or $3.0 \mu \mathrm{L} \mathrm{L}^{-1}$ EUG (Odontofarma ${ }^{\circledR}$, Porto Alegre, Brazil), or 10 or $20 \mu \mathrm{L}$ $\mathrm{L}^{-1}$ EOL (this oil was obtained according to Salbego et al., 2014). These compounds were first diluted in ethanol (1:10). The concentrations used in this study have been previously shown to cause only sedation in silver catfish (Becker et al., 2012; Salbego et al., 2014). Water parameters were monitored before and after transport, as described in Salbego et al. (2014), with the overall values (mean \pm SEM) at the end of transport as follows: dissolved oxygen $\left(8.29 \pm 0.98 \mathrm{mg} \mathrm{L}^{-1}\right)$, carbon dioxide $\left(58.13 \pm 2.51 \mathrm{mg} \mathrm{L}^{-1}\right)$, alkalinity $\left(30.89 \pm 2.09 \mathrm{mg} \mathrm{CaCO}_{3} \mathrm{~L}^{-1}\right)$, water hardness $\left(22.78 \pm 1.64 \mathrm{mg} \mathrm{CaCO}_{3} \mathrm{~L}^{-1}\right), \mathrm{pH}(6.07 \pm 0.07)$, temperature $\left(26.33 \pm 0.81^{\circ} \mathrm{C}\right)$, total ammonia nitrogen $(3.21 \pm 0.16 \mathrm{mg}$ $\left.\mathrm{L}^{-1}\right)$ and unionized ammonia $\left(0.0023 \pm 0.0002 \mathrm{mg} \mathrm{L}^{-1}\right)$. The water quality parameters during transport remained within the recommended values for this species, as previously reported by Salbego et al. (2014).

After transport, fish were euthanized by spinal cord section and tissues (brain, muscle and liver) were carefully removed, placed on ice and then stored at $-20 \mathrm{C}$ for one week until analysis of the biochemical parameters. The methodology of this experiment was approved by the Ethical and Animal Welfare Committee of the Universidade Federal de Santa Maria (Process nº 046/2010).

\subsection{Metabolic parameters}

Portions of liver and muscle tissues were weighed and homogenized with a TURRAX type homogenizer (Marconi Equipment for Laboratory Industry Ltd.). Tissues were homogenized in $1 \mathrm{~mL}$ of $10 \%$ TCA (trichloroacetic acid) to obtain an acid deproteinized extract which was used to measure lactate concentrations and $1 \mathrm{~mL}$ of $6 \mathrm{~N}$ $\mathrm{KOH}$ was then added to the homogenate and the mixture was placed in a water bath to obtain a basic extract, from 
which protein and glycogen concentrations were measured. The homogenates were then centrifuged at $3,000 \mathrm{~g}$ for $5 \mathrm{~min}$ and were used for determination of glycogen (Dubois et al., 1956), lactate (Harrower and Brown, 1972) and total protein concentrations (Lowry et al., 1951).

\subsection{Acetylcholinesterase (AChE) assay}

The AChE (E.C. 3.1.1.7) activity was measured using the method described by Ellman et al. (1961). Brain and muscle tissues $(30 \mathrm{mg}$ ) were weighed and homogenized in a Potter Elvejhem glass/Teflon homogenizer with $50 \mathrm{mM}$ sodium phosphate buffer, $\mathrm{pH} 7.2$, and $1 \%$ Triton $\mathrm{X}-100$. The homogenate was then centrifuged for $10 \mathrm{~min}$ at $3,000 \times \mathrm{g}$ at $5{ }^{\circ} \mathrm{C}$ and activity was measured in the supernatant. Aliquots of supernatant $(50 \mu \mathrm{L}$ for brain and $100 \mu \mathrm{L}$ for muscle) were incubated at $30^{\circ} \mathrm{C}$ for $2 \mathrm{~min}$ with a solution containing $0.1 \mathrm{M}$ sodium phosphate buffer, $\mathrm{pH} 7.5$, and $1 \mathrm{mM} \mathrm{DTNB}$. After the incubation period, the reaction was initiated by the addition of acetylthiocoline $(0.5 \mathrm{mM})$. The final volume of the whole reaction was $2.0 \mathrm{~mL}$. The absorbance at $412 \mathrm{~nm}$ was measured for 2 min using a spectrophotometry (Femto Scan spectrophotometer).

\subsection{Oxidative parameters}

The protein carbonyl (PC) levels in the liver were determined using the method described by Yan et al. (1995), with some modifications. Hepatic tissue was homogenized in 10 volumes $(\mathrm{w} / \mathrm{v})$ of $10 \mathrm{mM}$ Tris- $\mathrm{HCl}$ buffer, $\mathrm{pH}$ 7.4, using a glass homogenizer. Soluble protein $(1 \mathrm{~mL})$ was reacted with $10 \mathrm{mM}$ DNPH in $2 \mathrm{~N}$ hydrochloric acid $(0.2 \mathrm{~mL})$. After incubation at room temperature for $1 \mathrm{~h}$ in the dark, $0.5 \mathrm{~mL}$ of denaturing buffer $(150 \mathrm{mM}$ sodium phosphate buffer, pH 6.8, containing 3.0\% SDS), $2.0 \mathrm{~mL}$ of heptane $(99.5 \%)$, and $2.0 \mathrm{~mL}$ of ethanol $(99.8 \%)$ were added sequentially, homogenized with a TURRAX type homogenizer for $40 \mathrm{~s}$, and centrifuged at 10,000 $x \mathrm{~g}$ for $15 \mathrm{~min}$. The protein isolated from the interface was then washed two times by resuspension in ethanol/ethyl acetate (1:1) and suspended in $1 \mathrm{~mL}$ of denaturing buffer. The absorbance of each DNPH sample was measured at $370 \mathrm{~nm}$ in a spectrophotometer and compared with the corresponding blank sample, and total carbonylation was calculated using a molar extinction coefficient of $22,000 \mathrm{M} \mathrm{cm}^{-1}$.

The oxidative damage to lipids was estimated using the TBARS assay measured according to Buege and Aust (1978). Aliquots of supernatant $(0.25 \mathrm{~mL})$ from liver were mixed with $10 \%$ TCA $(0.25 \mathrm{~mL})$ and $0.67 \%$ thiobarbituric acid $(0.5 \mathrm{~mL})$ and adjusted to a final volume of $1.0 \mathrm{~mL}$. The reaction mixture was placed in a microcentrifuge tube and incubated for $15 \mathrm{~min}$ at $95{ }^{\circ} \mathrm{C}$. After cooling, the mixture was centrifuged at 5,000 $\times \mathrm{g}$ for $15 \mathrm{~min}$, and the optical density was measured at $532 \mathrm{~nm}$ using a spectrophotometer.

\subsection{Protein determination}

The protein levels were spectrophotometrically estimated by the method of Bradford (1976), using bovine serum albumin as a standard.

\subsection{Enzymatic and nonenzymatic parameters}

Glutathione-S-transferase (GST) activity in the liver was measured according to Habig et al. (1974) using 1-chloro-2,4-dinitrobenzene (CDNB) as a substrate. CDNB $(0.15 \mathrm{~mL})$ was added to a mixture containing $2.5 \mathrm{~mL}$ potassium phosphate buffer $(20 \mathrm{mM}, \mathrm{pH} 6.5)$, $0.3 \mathrm{~mL}$ reduced glutathione $(10 \mathrm{mM})$ and $0.05 \mathrm{~mL}$ of homogenate. The formation of S-2,4-dinitrophenyl glutathione was monitored by the increase in absorbance at $340 \mathrm{~nm}$ compared to the blank (containing all reaction ingredients but no sample). The extinction coefficient used for CDNB was $9.6 \mathrm{mM} \mathrm{cm}^{-1}$.

The content of nonprotein thiol groups (NPSH) in the liver was indirectly determined by the colorimetric method of Ellman (1959). An aliquot of the hepatic supernatant $(1.0 \mathrm{~mL})$ was mixed with $10 \%$ TCA $(1.0 \mathrm{~mL})$ followed by centrifugation. Supernatants $(0.25 \mathrm{~mL})$ were then mixed with $10 \mathrm{mM}$ 5,5'-dithio-bis(2-nitrobenzoic acid) (DTNB; $0.05 \mathrm{~mL})$ and $0.5 \mathrm{mM}$ phosphate buffer, $\mathrm{pH} 6.8(0.7 \mathrm{~mL})$. The optical density of the reaction product was read at 412 $\mathrm{nm}$ on a spectrophotometer.

\subsection{Statistical analysis}

All data are represented as mean $\pm \mathrm{SEM}$. Homogeneity of variances was tested using the Levene test. Data that presented homogeneous variances were compared by one-way ANOVA and Tukey's test. Nonparametric data were analyzed by Kruskal-Wallis and comparisons of mean ranks. Analyses were performed using the software Statistica, version 7.0 (StatSoft, Tulsa, OK), and the minimum significance level was set at $\mathrm{P}<0.05$.

\section{Results}

No mortality was observed in this experiment after four hours of transport. Glycogen and lactate levels in the liver and muscle were significantly lower in all groups transported with EUG and EOL compared to the control group. The total protein values were higher in both tissues of fish transported with EUG and only in muscle of fish transported with $20 \mu \mathrm{L} \mathrm{L}^{-1}$ EOL when compared to the control fish (Table 1). Brain AChE activity was significantly lower in fish transported under all tested concentrations of EUG and EOL compared to the control group, but muscle AChE activity was significantly lower only in fish transported with $1.5 \mu \mathrm{L} \mathrm{L}^{-1}$ EUG compared to control fish (Figure 1).

In the liver, PC (Figure 2A) and NPSH (Figure 3A) levels were significantly higher in fish transported with EUG and EOL, while TBARS levels (Figure 2B) were significantly lower in these groups compared to the control. Liver GST activity was significantly lower in fish transported with both EUG concentrations compared to control fish (Figure 3B).

\section{Discussion}

Housing of silver catfish in water containing eugenol and essential oil of Lippia alba at sedative concentrations is sufficient to improve some physiological indicators during 
Table 1. Metabolites in tissues of silver catfish, Rhamdia quelen, after transport (four hours) with eugenol (EUG) or essential oil of Lippia alba (EOL) added to the water.

\begin{tabular}{|c|c|c|c|c|c|}
\hline Tissues & & & Treatments & & \\
\hline Metabolites & Control & EUG $\left(1.5 \mu L L^{-1}\right)$ & EUG $\left(3.0 \mu L L^{-1}\right)$ & $\operatorname{EOL}\left(10 \mu L L^{-1}\right)$ & $\operatorname{EOL~}\left(20 \mu L L^{-1}\right)$ \\
\hline \multicolumn{6}{|l|}{ Liver } \\
\hline Glycogen & $30.61 \pm 1.59^{a}$ & $16.76 \pm 0.92^{b}$ & $14.87 \pm 0.79^{b}$ & $15.22 \pm 0.30^{\mathrm{b}}$ & $14.80 \pm 0.58^{b}$ \\
\hline Lactate & $17.84 \pm 0.30^{\mathrm{a}}$ & $12.24 \pm 0.36^{\mathrm{b}}$ & $7.27 \pm 0.18^{\mathrm{c}}$ & $6.51 \pm 0.22^{\mathrm{c}}$ & $6.64 \pm 0.16^{\mathrm{c}}$ \\
\hline Protein & $186.25 \pm 7.07^{\mathrm{c}}$ & $252.05 \pm 9.07^{\mathrm{b}}$ & $319.00 \pm 4.22^{\mathrm{a}}$ & $195.12 \pm 8.50^{\mathrm{c}}$ & $199.25 \pm 8.11^{\mathrm{c}}$ \\
\hline \multicolumn{6}{|l|}{ Muscle } \\
\hline Glycogen & $7.24 \pm 0.13^{\mathrm{a}}$ & $4.27 \pm 0.15^{\mathrm{b}}$ & $3.86 \pm 0.08^{\mathrm{bc}}$ & $3.54 \pm 0.12^{\mathrm{c}}$ & $3.61 \pm 0.04^{\mathrm{c}}$ \\
\hline Lactate & $21.50 \pm 0.31^{\mathrm{a}}$ & $17.35 \pm 0.23^{b}$ & $15.74 \pm 0.20^{c}$ & $17.31 \pm 0.25^{\mathrm{b}}$ & $15.86 \pm 0.36^{c}$ \\
\hline Protein & $85.37 \pm 4.22^{c}$ & $139.50 \pm 3.85^{\mathrm{b}}$ & $151.00 \pm 1.86^{\mathrm{ab}}$ & $90.44 \pm 4.01^{\mathrm{c}}$ & $153.62 \pm 2.76^{\mathrm{a}}$ \\
\hline
\end{tabular}

Values are expressed as mean \pm SEM ( $n=12$ per treatment). Different letters in the rows indicate significant difference between treatments (one-way ANOVA and Tukey's test; $\mathrm{P}<0.05$ ). Glycogen and lactate were expressed in $\mu \mathrm{mol} g$ tissue ${ }^{-1}$. Protein was expressed in mg protein $\mathrm{g} \mathrm{tissue}^{-1}$.

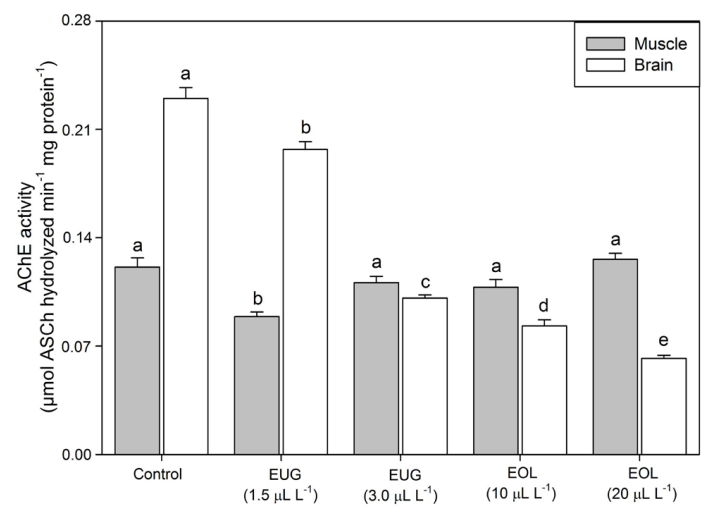

Figure 1. Brain and muscle AChE activity of silver catfish, Rhamdia quelen, after four hours of transportation in water containing eugenol (EUG) and essential oil of Lippia alba (EOL). Values are presented as mean \pm SEM. Different letters indicate significant differences between treatments for the same tissue (one-way ANOVA and Tukey's test; $\mathrm{P}<0.05)$.

transport (Azambuja et al., 2011; Becker et al., 2012). Our results demonstrated that silver catfish transported in water containing EUG and EOL showed lower glycogen levels in both liver and muscle tissue. This finding suggests that higher amounts of glycogen were broken down in order to supply energy during transport in the presence of these anesthetics. In the current study, the addition of EUG and EOL to the transport water prevented the increase in lactate levels observed in control silver catfish tissues, suggesting a reduction in anaerobic metabolism under these sedating conditions. Matrinxã (Brycon amazonicus) anesthetized with benzocaine or 2-phenoxyethanol or transported in water containing clove oil also presented lower lactate levels (Inoue et al., 2004, 2005). The results of the present study suggest that the addition of EUG and EOL may reduce oxygen consumption, ultimately improving the physiological condition of fish during transport.
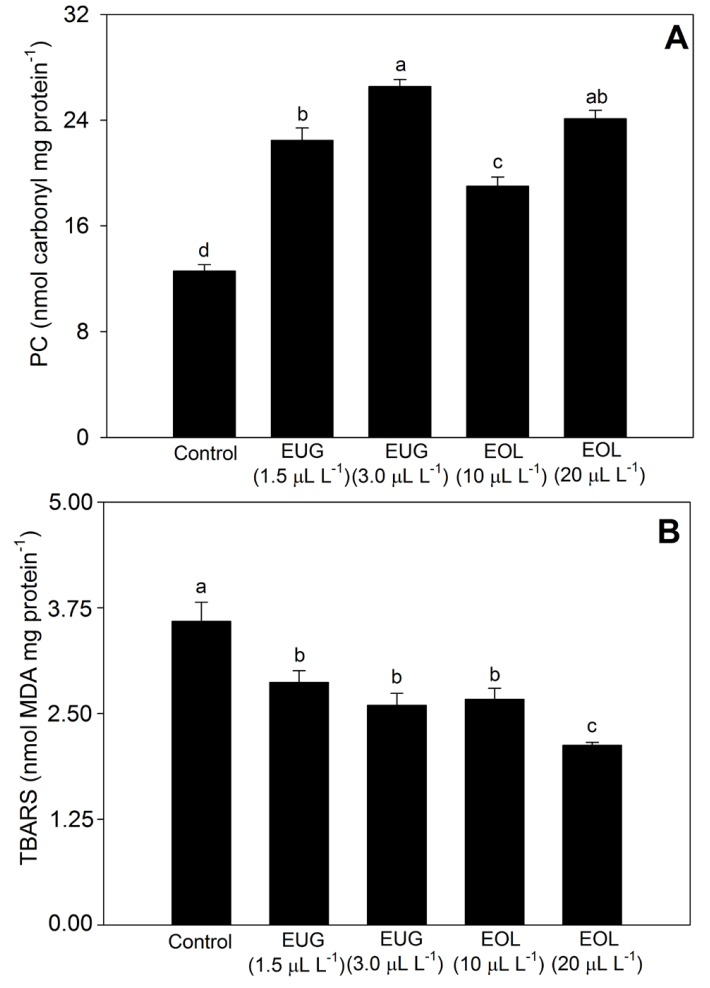

Figure 2. Protein carbonyl (PC) (A) and TBARS levels (B) in the liver of silver catfish, Rhamdia quelen, after four hours of transportation in water containing eugenol (EUG) and essential oil of Lippia alba (EOL). Values are presented as mean \pm SEM. Different letters indicate significant differences between treatments for the same tissue (one-way ANOVA and Tukey's test; $\mathrm{P}<0.05$ ).

Stress negatively affects protein metabolism, inhibiting the synthesis and stimulating the catabolism of proteins (Mommsen et al., 1999; Becker et al., 2016; Salbego et al., 2015; Toni et al., 2015). The addition of EUG and EOL to the water during silver catfish transport likely reduced protein catabolism, since protein levels were higher in the muscle and liver than in control group at the end of transport. 


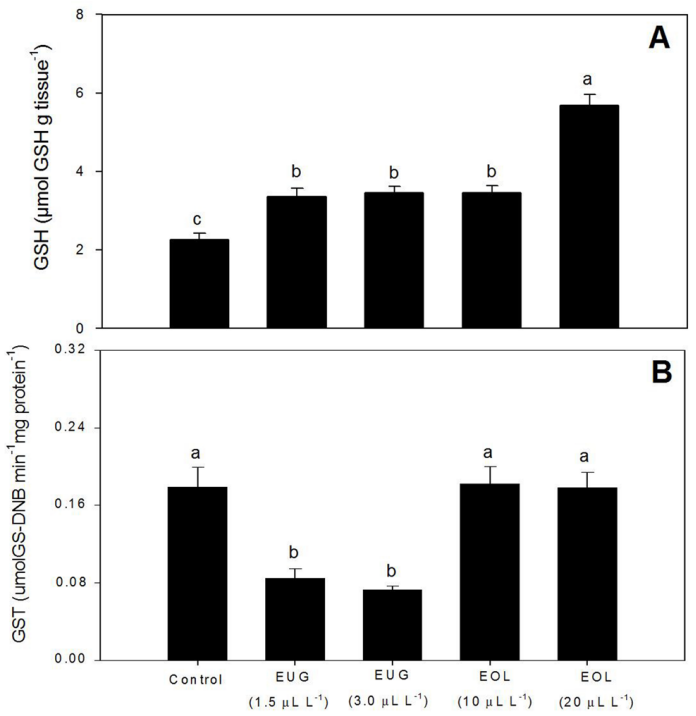

Figure 3. Nonprotein thiol group (NPSH) (A) levels and glutathione-S-transferase (GST) (B) activity in the liver of silver catfish, Rhamdia quelen, after four hours of transportation in water containing eugenol (EUG) and essential oil of Lippia alba (EOL). Values are presented as mean \pm SEM. Different letters indicate significant differences between treatments for the same tissue (one-way ANOVA and Tukey's test; $\mathrm{P}<0.05$ ).

The addition of EUG and EOL to the transport water decreased AChE activity in the brains of silver catfish. The inhibitory effect of EOL was expected since the main compound present in this chemotype is linalool (Vale et al., 1999, 2002), which has been shown to inhibit AChE in insects (Blenau et al., 2012) and in the electric eel, Electrophorus electricus (López et al., 2015). EUG has also been shown to inhibit AChE in the electric eel (López et al., 2015). Based on our results, it appears that the effects of these compounds on AChE activity in brain and muscle apparently depend on the concentration of the anesthetic in the tissue, because the higher the EOL and EUG concentration, the lower the brain AChE activity. However, transport of silver catfish in higher concentrations of EOL (30-40 $\mu \mathrm{L} \mathrm{L}^{-1}$ ) did not alter brain AChE activity compared to control group (Salbego et al., 2014) and in the present study the lowest EUG concentration tested significantly decreased muscle AChE activity, while the highest did not. Therefore, it seems that there are specific concentration ranges of EOL and EUG that are effective in altering AChE activity. The activity of this enzyme was lower in rat brain anesthetized with ketamine (Mazzanti et al., 1986) and in hippocampus and midbrain of guinea pigs after anesthesia with halothane (Lintern et al., 2000), but did not change in brain and muscle of silver catfish anesthetized with the essential oil of Aloysia gratissima (Benovit et al., 2015).

Protein carbonyl content is actually the most commonly used marker of protein oxidation (Almroth et al., 2005; Salbego et al., 2014, 2015). In this study, silver catfish transported with EUG and EOL showed higher PC content than control fish, indicating higher protein oxidation. However, the addition of EUG and EOL to the transport water protected against oxidative damage of lipids, since TBARS levels were lower in the liver of silver catfish transported with both compounds than those transported in only water. The attenuation of oxidative damage may also be favored by the efficiency of the antioxidant defense system (Goyal et al., 2013). Increases in NPSH levels attenuate oxidative stress (Ungvari et al., 2009; Yonar, 2012; Salbego et al., 2014, 2015) and the higher NPSH content in the liver of fish after transport in EUG- and EOL-containing water may have prevented lipid damage. On the other hand, GST activity was lower in the liver of silver catfish transported with EUG, while the addition of EOL did not affect the activity of this enzyme. As observed with AChE activity, the effects of both anesthetics on oxidative stress parameters were dependent on the concentration used. In the present study, the effects of EOL on NPSH, TBARS and PC levels in the liver were higher than control at the highest concentration tested. The EUG concentration affected only the PC levels in the liver. In a previous study, TBARS levels were lower in the liver of silver catfish transported for $6 \mathrm{~h}$ in water containing $10 \mu \mathrm{L}$ $\mathrm{L}^{-1}$ EOL when compared to fish transported without EOL (Azambuja et al., 2011). Silver catfish pre-sedated with EOL and transported in water containing $30-40 \mu \mathrm{L} \mathrm{L}^{-1}$ EOL presented some advantages (lower body ion loss and ammonia excretion) compared to the control group (Becker et al., 2016), but those transported in $30 \mu \mathrm{L} \mathrm{L}^{-1}$ EOL (but not those transported in $40 \mu \mathrm{L} \mathrm{L}^{-1} \mathrm{EOL}$ ) showed higher TBARS and PC levels in the liver than control fish (Salbego et al., 2014). The use of EUG for transport of silver catfish at the concentrations tested in the present study reduced oxidative stress in these fish. This finding is in agreement with the recommendation of its use in the transport of silver catfish at these concentrations by Becker et al. (2012).

In conclusion, the addition of EUG and EOL to the transport water improved the oxidative status of silver catfish, as evidenced mainly by lower TBARS and higher NPSH levels, compared to controls. The analyzed tissues received a sufficient supply of oxygen during transport, since anaerobic metabolism was reduced and no protein catabolism was observed. Both anesthetics reduced brain AChE activity at the concentrations tested. Therefore, the addition of EUG (1.5 or $\left.3.0 \mu \mathrm{LL}^{-1}\right)$ or EOL ( 10 or $20 \mu \mathrm{L} \mathrm{L}^{-1}$ ) to the water is advisable when transporting silver catfish.

\section{Acknowledgements}

This study was supported by research funds from the Fundação de Amparo à Pesquisa do Estado do Rio Grande do Sul (FAPERGS/PRONEX, process 10/0016-8) and the Conselho Nacional de Pesquisa e Desenvolvimento Científico (CNPq, process 470964/2009-0). J. Salbego, C. Toni and C.C. Menezes received $\mathrm{PhD}$ fellowships from the Coordenação de Aperfeiçoamento de Pessoal de Nível 
Superior (CAPES). B. Baldisserotto, V. L. Loro and B. M. Heinzmann received research fellowships, and A.G. Becker received a PhD fellowship from CNPq. The authors are grateful to Dr. Maria Amália Pavanato for the critical reading of this manuscript.

\section{References}

ALMROTH, B.C., STURVE, J., BERGLUND, A. and FÖRLIN, L., 2005. Oxidative damage in eel pout (Zoarces viviparus), measured as protein carbonyls and TBARS, as biomarkers. Aquatic Toxicology (Amsterdam, Netherlands), vol. 73, no. 2, pp. 171-180. PMid:15917092. http://dx.doi.org/10.1016/j.aquatox.2005.03.007.

AZAMBUJA, C.R., MATTIAZZI, J., RIFFEL, A.P.K., FINAMOR, I.A., GARCIA, L.O., HELDWEIN, C.G., HEINZMANN, B.M., BALDISSEROTTO, B., PAVANATO, M.A. and LLESUY, S.F., 2011. Effect of the essential oil of Lippia alba on oxidative stress parameters in silver catfish (Rhamdia quelen) subjected to transport. Aquaculture (Amsterdam, Netherlands), vol. 319, no. 1-2, pp. 156-161. http://dx.doi.org/10.1016/j.aquaculture.2011.06.002.

BALDISSEROTTO, B., RADÜNZ NETO, J. and BARCELLOS, L.G., 2010. Jundiá (Rhamdia sp.). In: B. BALDISSEROTTO and L.C. GOMES, eds. Espécies nativas para piscicultura no Brasil. 2. ed. Santa Maria: Ed. UFSM. pp. 301-323.

BECKER, A.G., PARODI, T.V., HELDWEIN, C.G., ZEPPENFELD, C.C., HEINZMANN, B.M. and BALDISSEROTTO, B., 2012. Transportation of silver catfish, Rhamdia quelen, in water with eugenol and the essential oil of Lippia alba. Fish Physiology and Biochemistry, vol. 38, no. 3, pp. 789-796. PMid:21972065. http://dx.doi.org/10.1007/s10695-011-9562-4.

BECKER, A.G., PARODI, T.V., ZEPPENFELD, C.C., SALBEGO, J., CUNHA, M.A., HELDWEIN, C.G., LORO, V.L., HEINZMANN, B.M. and BALDISSEROTTO, B., 2016. Pre-sedation and transport of Rhamdia quelen in water containing essential oil of Lippia alba: metabolic and physiological response. Fish Physiology and Biochemistry, vol. 42, no. 1, pp. 73-81. PMid:26297516. http:// dx.doi.org/10.1007/s10695-015-0118-x.

BENOVIT, S.C., SILVA, L.L., SALBEGO, J., LORO, V.L., MALLMANN, C.A., BALDISSEROTTO, B., FLORES, E.M. and HEINZMANN, B.M., 2015. Anesthetic activity and bioguided fractionation of the essential oil of Aloysia gratissima (Gillies \& Hook.) Tronc. in silver catfish Rhamdia quelen. Anais da Academia Brasileira de Ciencias, vol. 87, no. 3, pp. 1675-1689. PMid:26221984. http://dx.doi.org/10.1590/00013765201520140223 .

BLENAU, W., RADEMACHER, E. and BAUMANN, A., 2012. Plant essential oils and formamidines as insecticides/acaricides: what are the molecular targets? Apidologie, vol. 43, no. 3, pp. 334-347. http://dx.doi.org/10.1007/s13592-011-0108-7.

BRADFORD, M.M., 1976. A rapid and sensitive method for the quantification of microgram quantities of protein utilizing the principle of protein-dye binding. Analytical Biochemistry Journal, vol. 72, no. 1-2, pp. 248-254. PMid:942051. http:// dx.doi.org/10.1016/0003-2697(76)90527-3.

BUEGE, J.A. and AUST, S.D., 1978. Microssomal lipid peroxidation. Methods in Enzymology, vol. 52, pp. 302-309. PMid:672633. http://dx.doi.org/10.1016/S0076-6879(78)52032-6.

COOKE, S.J., SUSKI, C.D., OSTRAND, K.G., TUFTS, B.L. and WAHL, D.H., 2004. Behavioral and physiological assessment of low concentrations of clove oil anaesthetic for handling and transporting largemouth bass (Micropterus salmoides). Aquaculture (Amsterdam, Netherlands), vol. 239, no. 1-4, pp. 509-529. http:// dx.doi.org/10.1016/j.aquaculture.2004.06.028.

CUNHA, M.A., BARROS, F.M.C., GARCIA, L.O., VEECK, A.P.L., HEINZMANN, B.M., LORO, V.L., EMANUELLI, T. and BALDISSEROTTO, B., 2010a. Essential oil of Lippia alba: a new anesthetic for silver catfish, Rhamdia quelen. Aquaculture (Amsterdam, Netherlands), vol. 306, no. 1-4, pp. 403-406. http:// dx.doi.org/10.1016/j.aquaculture.2010.06.014.

CUNHA, M.A., ZEPPENFELD, C.C., GARCIA, L.O., LORO, V.L., FONSECA, M.B., EMANUELLI, T., VEECK, A.P.L., COPATTI, C.E. and BALDISSEROTTO, B., 2010b. Anesthesia of silver catfish with eugenol: time of induction, cortisol response and sensory analysis of fillet. Ciência Rural, vol. 40, no. 10, pp. 2107-2114. http://dx.doi.org/10.1590/S0103-84782010001000009.

DUBOIS, M., GILLES, K.A., HAMILTON, J.K., REBERS, P.A. and SMITH, F., 1956. Colorimetric method for determination of sugars and related substances. Analytical Chemistry, vol. 28, no. 3, pp. 350-358. http://dx.doi.org/10.1021/ac60111a017.

ELLMAN, G.L., 1959. Tissue sulfhydryl groups. Archives of Biochemistry and Biophysics, vol. 82, no. 1, pp. 70-77. PMid:13650640. http://dx.doi.org/10.1016/0003-9861(59)90090-6.

ELLMAN, G.L., COURTNEY, K.D., ANDRES JUNIOR, V. and FEATHER-STONE, R.M., 1961. A new and rapid colorimetric determination of acetylcholinesterase activity. Biochemical Pharmacology, vol. 7, no. 2, pp. 88-95. PMid:13726518. http:// dx.doi.org/10.1016/0006-2952(61)90145-9.

GONÇALVES, A.F.N., SANTOS, E.C.C., FERNANDES, J.B.K. and TAKAHASHI, L.S., 2008. Mentol e eugenol como substitutos da benzocaína na indução anestésica de juvenis de pacu. Acta Scientiarum Biological Sciences, vol. 30, pp. 339-344.

GOYAL, A.K., MISHRA, T., BHATTACHARYA, M., KAR, P. and SEN, A., 2013. Evaluation of phytochemical constituents and antioxidant activity of selected actinorhizal fruits growing in the forests of Northeast India. Journal of Biosciences, vol. 38, no. 4, pp. 797-803. PMid:24287659. http://dx.doi.org/10.1007/ s12038-013-9363-2.

HABIG, W.H., PABST, M.J. and JAKOBY, W.B., 1974. Glutathione $S$-transferases: the first enzymatic step in mercapturic acid formation. The Journal of Biological Chemistry, vol. 249, no. 22, pp. 7130-7139. PMid:4436300.

HARROWER, J.R. and BROWN, C.H., 1972. Blood lactic acid: a micromethod adapted to field collection of microliter samples. Journal of Applied Physiology, vol. 32, no. 5, pp. 709-711. PMid:5038862.

HUDETZ, A.G., WOOD, J.D. and KAMPINE, J.P., 2003. Cholinergic reversal of isoflurane anesthesia in rats as measured by cross-approximate entropy of the electroencephalogram. Anesthesiology, vol. 99, no. 5, pp. 1125-1131. PMid:14576549. http://dx.doi.org/10.1097/00000542-200311000-00019.

INOUE, L.A.K.A., AFONSO, L.A.B., IWAMA, G.K. and MORAES, G., 2005. Effects of clove oil on the stress response of matrinxã (Brycon cephalus) subjected to transport. Acta Amazonica, vol. 35, no. 2, pp. 289-295. http://dx.doi.org/10.1590/ S0044-59672005000200018.

INOUE, L.A.K.A., HACKBARTH, A. and MORAES, G., 2004. Avaliação dos anestésicos 2- phenoxyethanol e benzocaína no manejo do matrinxã (Brycon cephalus). Biodiversidade Pampeana, vol. 2, pp. 10-15. 
LEUNG, L.S., PETROPOUlOS, S., SHEN, B., LUO, T., HERRICK, I., RAJAKUMAR, N. and MA, J., 2011. Lesion of cholinergic neurons in nucleus basalis enhances response to general anesthetics. Experimental Neurology, vol. 228, no. 2, pp. 259-269. PMid:21295026. http://dx.doi.org/10.1016/j. expneurol.2011.01.019.

LINTERN, M.C., WETHERELL, J.R. and SMITH, M.E., 2000. Effect of halothane administration on acetylcholinesterase activity in guinea-pig muscle and brain. Neuroscience Letters, vol. 284, no. 1-2, pp. 101-104. PMid:10771172. http://dx.doi.org/10.1016/ S0304-3940(00)00986-1.

LÓPEZ, M.D., CAMPOY, F.J., PASCUAL-VILLALOBOS, M.J., MUNOZ-DELGADO, E. and VIDAL, C.J., 2015. Acetylcholinesterase activity of electric eel is increased or decreased by selected monoterpenoids and phenylpropanoids in a concentration-dependent manner. Chemico-Biological Interactions, vol. 229, pp. 36-43. PMid:25636489. http://dx.doi. org/10.1016/j.cbi.2015.01.006.

LOWRY, O.H., ROSEBROUGH, N.J., FARR, A.L. and RANDALL, R.J., 1951. Protein measurement with the Folin phenol reagent. The Journal of Biological Chemistry, vol. 193, no. 1, pp. 265275. PMid:14907713.

MATÉS, J.M., 2000. Effects of antioxidant enzymes in the molecular control of reactive oxygen species toxicology. Toxicology, vol. 153, no. 1-3, pp. 83-104. PMid:11090949. http://dx.doi.org/10.1016/ S0300-483X(00)00306-1

MAZZANTI, L., PASTUSZKO, A. and LENAZ, G., 1986. Effects of ketamine anesthesia on rat-brain membranes: fluidity changes and kinetics of acetylcholinesterase. Biochimica et Biophysica Acta, vol. 861, no. 1, pp. 105-110. PMid:3756149. http://dx.doi. org/10.1016/0005-2736(86)90376-7.

MOMMSEN, T.P., VIJAYAN, M.M. and MOON, T.W., 1999. Cortisol in teleosts: dynamics, mechanisms of action, and metabolic regulation. Reviews in Fish Biology and Fisheries, vol. 9, no. 3, pp. 211-268. http://dx.doi.org/10.1023/A:1008924418720.

PANKHURST, N.W., 2011. The endocrinology of stress in fish: an environmental perspective. General and Comparative Endocrinology, vol. 170, no. 2, pp. 265-275. PMid:20688064. http://dx.doi.org/10.1016/j.ygcen.2010.07.017.

PARODI, T.V., CUNHA, M.A., HELDWEIN, C.G., SOUZA, D.M., MARTINS, A.C., GARCIA, L.O. and WASIELESKY, W. Jr., 2012. The anesthetic efficacy of eugenol and the essential oils of Lippia alba and Aloysia triphylla in post-larvae and sub-adults of Litopenaeus vannamei (Crustacea, Penaeidae). Comparative Biochemistry and Physiology, vol. 155, no. 3, pp. 462-468. PMid:22198554.

ROSS, L.G. and ROSS, B., 2008. Anaesthetic and sedative techniques for aquatic animals. 3rd ed. Oxford: Blackwell Science.

ROUBACH, R., GOMES, L.C., FONSECA, F.A.L. and VAL, A.L., 2005. Eugenol as an efficacious anaesthetic for tambaqui, Colossoma macropomum (Cuvier). Aquaculture Research, vol. 36, no. 11, pp. 1056-1061. http://dx.doi.org/10.1111/j.13652109.2005.01319.x.

SALBEGO, J., BECKER, A.G., GONÇALVES, J.F., MENEZES, C.C., HELDWEIN, C.G., SPANEVELLO, R.M., LORO, V.L. and SCHETINGER, M.R.C., 2014. The essential oil from Lippia alba induces biochemical stress in the silver catfish (Rhamdia quelen) after transportation. Neotropical Ichthyology, vol. 12, no. 4, pp. 811-818. http://dx.doi.org/10.1590/1982-0224-20130178.

SALBEGO, J., BECKER, A.G., PARODI, T.V., ZEPPENFELD, C.C., GONÇALVES, J.F., LORO, V.L., MORSCH, V.M.M., SCHETINGER, M.R.C., MALDANER, G., MOREL, A.F. and BALDISSEROTTO, B., 2015. Methanolic extract of Condalia buxifolia added to transport water alters biochemical parameters of the silver catfish Rhamdia quelen. Aquaculture (Amsterdam, Netherlands), vol. 437, pp. 46-50. http://dx.doi.org/10.1016/j. aquaculture.2014.11.022.

TONI, C., MARTOS-SITCHA, J.A., BALDISSEROTTO, B., HEINZMANN, B.M., SILVA, L.L., MARTÍNEZ-RODRÍGUEZ, G. and MANCERA, J.M., 2015. Sedative effect of 2-phenoxyethanol and essential oil of Lippia alba on stress response in gilthead sea bream (Sparus aurata). Research in Veterinary Science, vol. 103, pp. 20-27. PMid:26679791. http://dx.doi.org/10.1016/j. rvsc.2015.09.006.

UNGVARI, Z., LABINSKYY, N., MUKHOPADHYAY, P., PINTO, J.T., BAGI, Z., BALLABH, P., ZHANG, C., PACHER, P. and CSISZAR, A., 2009. Resveratrol attenuates mitochondrial oxidative stress in coronary arterial endothelial cells. American Journal of Physiology, Heart and Circulatory Physiology, vol. 297, no. 5, pp. 1876-1881. PMid:19749157. http://dx.doi.org/10.1152/ ajpheart.00375.2009.

VALE, T.G., FURTADO, E.C. and SANTOS JUNIOR, J.G., 2002. Central effects of citral, myrcene and limonene, constituents of essential oil chemotypes from Lippia alba (Mill.) N.E. Brown. Phytomedicine, vol. 9, no. 8, pp. 709-714. PMid:12587690. http:// dx.doi.org/10.1078/094471102321621304.

VALE, T.G., MATOS, F.J., LIMA, T.C. and VIANA, G.S., 1999. Behavioral effects of essential oils from Lippia alba (Mill.) N. E. Brown chemotypes. Journal of Ethnopharmacology, vol. 67, no. 2, pp. 127-133. PMid:10619375. http://dx.doi.org/10.1016/ S0378-8741(98)00215-3.

VILLARES JUNIOR, G.A. and GOITEIN, R., 2015. Differences in the feeding of Rhamdia quelen (Siluriformes, Heptapteridae) in four distinct lotic systems. Brazilian Journal of Biology $=$ Revista Brasileira de Biologia. http://dx.doi.org/10.1590/1519-6984.20313.

YAN, L.J., TRABER, M.G. and PACKER, L., 1995. Spectrophotometric method for determination of carbonyls in oxidatively modified apolipoprotein B of human low-density lipoproteins. Analytical Biochemistry Journal, vol. 228, no. 2, pp. 349-351. PMid:8572318. http://dx.doi.org/10.1006/abio.1995.1362.

YONAR, M.E., 2012. The effect of lycopene on oxytetracyclineinduced oxidative stress and immunosuppression in rainbow trout (Oncorhynchus mykiss, W.). Fish \& Shellfish Immunology, vol. 32, no. 6, pp. 994-1001. PMid:22554571. http://dx.doi. org/10.1016/j.fsi.2012.02.012.

ZAHL, I.H., KIESSLING, A., SAMUELSEN, O.B. and OLSEN, R.E., 2010. Anesthesia induces stress in Atlantic salmon (Salmo salar), Atlantic cod (Gadus morhua) and Atlantic halibut (Hippoglossus hippoglossus). Fish Physiology and Biochemistry, vol. 36, no. 3, pp. 719-730. PMid:19680764. http://dx.doi. org/10.1007/s10695-009-9346-2. 